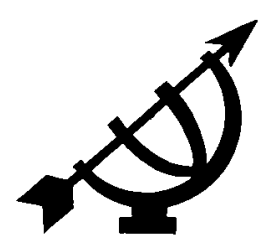

\title{
A cosmopolitan politics of loyalty
}

\author{
Michael Heyns \\ School of Philosophy \\ Potchefstroom Campus \\ North-West University \\ POTCHEFSTROOM \\ E-mail: filmfh@puknet.puk.ac.za
}

\section{Abstract}

\section{A cosmopolitan politics of loyalty}

While focusing on the thought of Charles Taylor the question whether the politics of loyalty can be part of a transcendental structure for society is discussed in this article. Classical patriotism, for instance, involves loyalty to public institutions and laws to enhance self-rule. In the twentieth century, however, classical patriotism became fused with nationalism (i.e. loyalty to culture), resulting in many instances in human suffering. Part of the explanation for this derailment is to be found in the Taylorian concept of the hypertrophy of autonomous freedom. The argument developed in this article links up with trends in liberalism and Taylor's own reasoning that hypertrophy can be curbed within a transcendental structure for society (i.e. a cosmopolitan politics of loyalty). However, in the liberalist trends (and also in Taylor's thought) tension exists between such a structure and the perception that loyalty politics is a mere particularism. As alternative I propose engagement between the cosmopolitan perspective and the various loyalties, with the latter a transcendental principle that needs to be applied in collaboration with other principles.

\section{Opsomming}

'n Kosmopolitiese politiek van lojaliteit

Terwyl gefokus word op die denke van Charles Taylor word die vraag of die politiek van lojaliteit deel kan wees van 'n universele normstruktuur in hierdie artikel bespreek. Klassieke patriotisme behels byvoorbeeld die lojaliteit aan openbare instellings en wette ter wille van selfregering. In die twintigste eeu het patriotisme egter vermeng geraak met nasionalisme (d.i. lojaliteit aan 'n spesifieke kultuur) met menslike lyding in baie gevalle as die resultaat. Vir 'n verklaring van hierdie ontsporing gebruik ek Taylor se konsep van die hipertrofie van 
outonome vryheid. Ek sluit aan by tendense in die liberalisme asook Taylor se eie denke en beredeneer die stelling dat hierdie hipertrofie ingeperk kan word binne 'n transendentale struktuur vir die samelewing (d.i. kosmopolitiese lojaliteitspolitiek). In sowel die liberalisme as in Taylor se denke is daar egter spanning tussen so 'n struktuur en die persepsie dat lojaliteitspolitiek bloot 'n vorm van partikularisme is. As alternatief stel ek 'n verbondenheid tussen 'n kosmopolitiese perspektief en die verskillende lojaliteite voor. Die verskillende lojaliteite is self ook ' $n$ transendentale beginsel wat toegepas moet word in samewerking met ander beginsels.

\section{Introduction}

For cosmopolitans the idea of taking patriotism and nationalism seriously is an outrage, because of the bigoted, jingoistic and bloody history of twentieth-century nationalism. Cosmopolitans operate with the perception that this kind of politics is only interested in the survival, interest and power of the own group against the cosmopolitan orientation with its openness to all people.

In order to develop a less declinatory view towards loyalty, I intend to focus on and reinterpret crucial aspects of the republican ideas of the Canadian philosopher, Charles Taylor. Taylor seems to have affinity for both a politics of loyalty and a cosmopolitan stance. It will be argued that his attempt to accommodate these seemingly opposites is the only alternative. Kal (2001:186), however, is of the opinion that a tension between cosmopolitanism and the autonomism associated with loyalty manifests itself inherently to Taylor's thought. If this conclusion is true, it implies that Taylor is stuck in some form and degree of dualism and that the contours of a cosmopolitan loyalty should go beyond Taylor.

I will thus embark on a search to connect the cosmopolitan stance and the politics of loyalty in a more integral way. Directing this attempt is a hunch that the dilemma between the exclusivity of loyalism and the sterility of cosmopolitanism is due to an absolutisation of either a legitimate loyalist morality or an impotent use of the transcendental order for society suggested by the concept cosmopolis ${ }^{1}$. This attempt to connect a cosmopolitan stance and the

1 Toulmin (1992:67-68) traces the meaning of cosmopolis to the ancient Greek distinction between the order of nature (cosmos) over which humans have a mere marginal command and the order of society, which is fully under human control. Cosmopolis represented to ancient Greeks the dream of an overall harmony and fusion between these two orders. Stoics especially used the word in the sense of order implying that "reason" binds all things together. "The 
politics of loyalty will be linked with a diagnosis that sees a fully secularised and autonomist freedom as the root-cause of both exclusivist loyalism and sterile non-commitment ${ }^{2}$. This autonomism represses the idea of a societal structure that provides a just (not repressed but also no over-emphasised) place and function to loyalties.

I will argue that we should look for an integral view in the idea of particular loyalties that receives a legitimate and necessary place in a structure for society.

\section{Patriotism and nationalism}

A first important step is to define the politics of loyalty. Widely used definitions can be obtained from college handbooks. Baradat (2003:58-60), for instance regards patriotism as an important part of nationalism. For Baradat patriotism implies the emotional or devotional acts accompaning nationalism - acts that express a loyalty and commitment to the nation-state. Nationalism, on the other hand, is seen by him as the actual theoretical or worldviewrelated content. Nationalism is the ideology (i.e. worldview and vision of a better life) of the modern nation-state. According to Baradat the main (and mainly unacceptable) features of this ideology are the following:

- its exclusive focus on the national group as the principal political unit;

- the demand that the national group be served by the state;

- the assumption that politics determine the identity of the human being (family for instance should take second place);

- that the identity of some national group should be the ultimate unifying factor - an assumption that leads to the subordination of

practical idea that human affairs are influenced by, and proceed in step with heavenly affairs, changes into the philosophical idea that the structure of Nature reinforces a rational Social Order". My positive allusion to "cosmopolis" is not to an order bound by "reason" but to a creational structure that can possibly give positive direction to the diversity and contingency in which we find ourselves.

2 Kal (2001:182-183) for instance diagnoses the common virus in both noncommitment and jingoism as the modernist motive of autonomist freedom. In the case of jingoism a particular nation becomes the project for a limitless consciousness of freedom and power. Autonomism is also behind this kind of cosmopolitanism that promises freedom from confinement within a particular community. 
all other identities, values and interests to those of this national group.

Baradat's (2003:46-47) definition of nation is in terms of ethnicity or culture rather than citizenship. Several nations can thus be citizens of the same state, while a single nation can be divided among several states. This description implies that a national group needs not necessarily be a political concept that demands a strong and formal connection between nation and state. It also means that one should distinguish between two kinds of social groups, that is, nations and states. I will therefore assume that a legitimate nationalism refers to loyalty towards the ethnic, culture or language group within the bounds of general moral norms that control all human relations (i.e. a cosmopolitan nationalism). It is of course a possible and indeed a popular practice to fuse nation and citizenry, which makes the national group the main political unit with the unacceptable features mentioned above of reducing human identity to that of a political being; of reducing a political unit to a single national group and thus to suppress all other identities.

My difference with Baradat concerns his description of patriotism as the emotional and activist side of nationalism. However, patriotism should rather be related to the state than to nationalism. Patriotism has indeed an emotional, even devotional, as well as an activist component. But patriotism also includes a worldview-related - and even theoretical- explanation and justification of the object (the state) of patriotic emotions and actions.

For ancient people as well as for people of early modernity, patriotism was a strong identification with public institutions through which collective self-rule is possible - a meaning which to my mind still highlights the proper sense of the word patriotism. Behind this meaning the idea lies that a person lives a "higher life" when he is part of a "self-managing people". "Self-management became possible, because men were willing to die for the patria, for the laws, because they devoted themselves to res publica" (Taylor, 1993:41)3.

Taylor $(1993: 41,42,45,46)$ interprets nationalism as the modern manifestation of this old ideal of collective self-rule and loyalty to the

3 Cf. also Viroli (1995:19-20) who emphasises that the ancient concept of patriotism had two important nuances of meaning: Firstly, it implies an identification of patria with res publica, common liberty and common good and secondly, it assumes that citizens owe their country a love similar to the affection of relatives - a love that expresses itself in acts of service and care. 
laws of the polis. Nationalism is the demand for "self-determination", despite the modern erosion of local and religious communities. Identification with and self-rule through some group is fundamental for moderns. Thus, if people are fundamentally dependent on group membership and previous identifications are no longer viable, the obvious alternative is that of "the speaking animal, namely, nationality based on language".

In the light of my earlier distinctions between state and nation, as well as between patriotism and nationalism, Taylor clearly conflates these loyalties and social functions too readily. 4 Patriotism should be seen as loyalty to the state and democratic processes while the loyalty of nationalism is to a community defined by a common culture, ethnicity or language. Aggressive versions of nationalism usually try to "invade" the state in order to make it the primary instrument for maintaining and establishing loyalty to a single culture, ethnicity or language. This emphasis assigns a totalitarian role to some ethnic, cultural or language identity and the state's primary task, that is, to administer justice, is not focused on. This derailment, however, does not annihilate a legitimate communal loyalty to specific cultures and languages that are also important contributing sources for making us the persons we are. The mentioned derailment also does not exempt the state from any responsibility to protect these sources within its borders.

Patriotism as a loyalty and commitment to the "common freedom" of all the citizens of a particular state can of course also assume totalitarian form. In this case the particular agenda of the state (i.e. usually of the government of that state), as the embodiment of the "common freedom", becomes a goal that overrides all other communal funtions. This overruling can take place for instance when the state tries to set and control the agenda and culture of all communities within its borders - from language groups, to sports associations to religious communities. Behind this kind of derailment of the object of patriotism is what Baradat (2003:51) calls "statism". According to this view, the "state is the most powerful form of human

4 This intuitive perception is also shared by Viroli (1995:8-9) who argues that nationalism assumes themes like cultural or ethnic unity and purity, while these themes receive no or very little attention in republican patriotism. Although Viroli admits that republicans also think that we have a moral obligation towards country because we owe our country our life, education, language and liberty, the main obligation towards country is "to protect the common liberty". He therefore thinks we should "think in terms of two languages, not a single language unfolding and changing over the centuries". 
organisation" which means that the state is not within the bounds of any normal form of moral restraint, because it sees itself as greater and above all other forms of community as well as in total control of the individual.

The point that needs to be stressed is that nationalism and patriotism should deal with different modes of loyalty: nationalism deals with culture and language, while patriotism deals with loyalty to the state. It is important to keep these two modes apart, although they will necessarily converge in the formation of human beings' identities. The reason for keeping them apart is because the invasion of the one by the other is a first indication that the invader is on its way to become a malignant totalitarianism. It is therefore important to reject all forms of fusion of nationalism and patriotism and to insist on a structure for society that allocates a legitimate place to both patriotism and nationalism. An important feature of such a legitimate place is to show loyalty only to the proper task of a particular kind of community. If a state for instance wants to be more than only the administrator of justice, citizens should refuse to be loyal to such a totalitarian enterprise.

\section{Nationalism and modernism}

Although Taylor's uncritical conflation of nationalism and patriotism can not be accepted, his account provides important insights into the relationship between this fusion and modern society.

Viroli (1995:10-11) is of the opinion that many contemporary political philosophers regard patriotism (and definitely also nationalism) as a hopelessly obsolete vestige of antiquity. Modern people want "freedom", perceived as existing only in the pleasures of private life. This attitude, Taylor argues, is not at all an accurate account of modern society. He argues that the nature of modern society provides the context for the fusion of nationalism and patriotism. For this aspect Taylor (1997:32-33) refers to Ernest Gellner's analysis, which characterises modern societies as economies that need to be serviced and managed by the state. Because these economies grow and change, they require a population that is occupationally and geographically mobile and homogeneous. This requirement implies that a standard language, enforced by the state, must replace all local dialects. Homogeneity as the "inescapable imperative of modernity" eventually appears on the surface as nationalism.

Taylor $(1997: 34,42)$ postulates that Gellner's account is incomplete. Some people assimilate without much protest and become part of a 
new nationalism, because they do not want to be economically disadvantaged, but others put up a fight. Faced with the "distasteful prospect" of homogenisation, they attempt to create a new polity/economy where their own language will be the official one. The point Taylor wants to stress is that nationalist struggles are not simply the result of a regression to premodern tribal identities, but are the product of a situation of rivalry that is "quintessentially modern in its structure and stakes".

It can nevertheless still be argued that although the context of nationalistic struggles is modern, the nationalist sentiment itself is primeval. Taylor (1997:43-45), however, argues that even the sentiment is modern. In many instances the rise of nationalism evolves from the refusal of the elite. Whoever does not accept a market-industrial economy, a bureaucratically organised state and popular rule will irredeemably fall behind in the power stakes. A successful adaptation to modernity is one where people find resources in their traditional culture to take on these new practices. There is thus in the process of change a "call to difference" felt by the modernising élite. Important is that the "call to difference" is experienced by the élite because of their sense of dignity. For them an imputation of inferiority against the stronger culture will remain until they adapt successfully. Dignity thus gives nationalism its emotive power.

Critics of Taylor point out that one cannot reduce the origin of a justified nationalism to only the emotion of dignity experienced by the élite group of a minority. Kymlicka (1997:60-63) thinks for instance that the reason why endangered cultures put up a fight, is quite simple: members of all cultures desire to live and work in their own culture. Kymlicka admits that this is a fair desire. He points out that the latter judgement is not only that of communitarians or conservatives, but also of liberals - he mentions Rawls, Humboldt, Mill, Berlin, Dworkin and Raz. Feinberg (1997:69-72) states that besides the emotional dimension (dignity), economic causes for nationalism are also significant (which Taylor also points out in the case of those who become part of a broader homogeneous nationalism). In many cases the élite are responding not to insults aimed at them, but to the desperate political and economic conditions of their compatriots.

Feinberg nevertheless admits that nationalism is not always simply sparked off by economic causes. In fact, we need to understand nationalism comprehensively and the mechanism of its creation can probably not be reduced to only dignity, or only economical factors, 
or only the nature of the modern state. We can probably agree that these factors, like aspirations, are justified and constitute a moderate nationalism. Nevertheless a very important link exists between these modern views and an aggressive fusion between nationalism and patriotism that needs further exploration. This link is obvious in the modernist notion of autonomism as yet another cause of current nationalism.

To understand this link, we should look at the difference between liberal and illiberal nationalism. An illiberal nationalism, according to Kymlicka (1997:63), is one that aims not only to maintain the own culture, but also to oppress dissidents or racial minorities within that culture and to dominate non-members outside the group. These aims will lead to campaigns of ethnic cleansing or prohibitions on the use of minority languages. The difference between liberal and illiberal nationalism needs to be explained. In other words, what are the causes of a malignant nationalism?

Taylor (1997:48) implicitly meets the critique of Kymlicka and Feinberg when he argues that the recognition of dignity accounts for the liberal nationalism of the élite, but not for nationalism as an illiberal popular movement. Nationalism (in the majority of cases) becomes a popular movement, simply because of the physical fears of a minority. This movement develops into a situation of distrust and hatred towards other groups with whom the minority shares a space. Each community harbours the suspicion that the other group initially mobilised itself and that the aggression of the own group is secondary and defensive in nature. In the end all groups are in the grip of a powerful nationalism "hell-bent on its own form of ethnically pure 'self-determination"'. This motivation has little to do with threatened dignity, but everything with a sense of physical threat, of fear of displacement and extermination by a hostile other. This explanation can takes us some distance towards an understanding of malignant nationalisms.

Taylor (1997:52-53) argues that nationalisms differ in what they want to take over. In liberal nationalisms, part of what is seen as the desirable modernity are the liberal values of rights and equal citizenship for all civilians, regardless of their differences. Tensions in this liberal nationalism exist between universal values and particular interests. But, says Taylor, these tensions can be managed for "there is no question of sacrificing universality on the altar of nation". Different to this approach are the nationalisms that do not include liberal values. In this respect the nation is defined purely ethnically and even racially and there is nothing in this 
nationalism to curb this exclusivism. It is significant that Taylor mentions that in this instance, modernity does not help at all - it rather aggravates things. When a sovereign national will is the aspiration and it becomes the source of all right, nothing will stand against it; the outsider has no place in this rule of popular sovereignty. In fact, outsiders are usually seen as contenders for the self-determination of the nation. If such a defensive nationalism takes a hold, the scene is ready for ethnic cleansing.

\section{Modernist freedom}

The latter remark about the connection between popular selfdetermination and a malignant nationalism, suggests that the context of modernist ideas of self-rule has a strong role in the origin of an illiberal nationalism. Taylor, however, does not elaborate directly on self-rule as a reason for the derailment of modern nationalism. Such an elaboration, however, can be done in terms of Taylor's own explanation of the modern moral order as a context for nationalism.

Taylor (1997:38; 2004b:9-11) depicts the current context for nationalism as similar to Benedict Anderson's explanation of modern states as "imagined communities". An important feature of modern social imaginary that Taylor borrows from Anderson, is that social entities are no longer visualised as grounded in something higher and other than "common action in secular time". In the premodern state a kingdom was seen to be based on the "Great Chain of Being" or on "an original law" - a view that originated from the perception that the state is "action-transcendent". Contract theory that regards people as coming together out of a state of nature and demanding self-determination, has changed all these perceptions.

According to Taylor (1993:46-47, 68-72) the collective form of autonomous freedom did not develop as a first choice for "emancipated humanism". The first phase (Hobbes and Locke) of modernity emphasised "man as an atomic subject" that only uses politics as an instrument. Autonomous freedom originated as a rejection of ancient views, which saw humans as "part of some cosmic order". The modern "free subject" is seen as someone "who follows an internal purpose and who owes no a priori allegiance to a pre-existing order but gives it only to structures that were created by his or her own consent". Accompanying this view was a notion of "efficacy," that is, the idea that a free subject should control himself and nature in order to attain his purposes. In this early version of modern freedom, the "need for a horizon of meaning", was ignored. 
The latter requirement was again brought to the fore by the Romantic phase, during which it was argued that for a person to discover his purposes in himself, he needs a horizon of meaning given to him. It is once again important that this horizon is provided by some group or tradition. According to Taylor, Romanticism implies a "deepening" of emancipation. Phase one emphasises individual autonomy "to the point where the necessity of social mediation has been lost", but in the second phase social "institutions and practices have been of crucial importance".

Taylor regards the motive of autonomy or self-determination as forming part of the context of nationalism. Taylor is not without critique of this motive. He (Taylor, 1993:59-61; 2004b:1) mentions that a "hypertrophy" of modernist motives can take place - a process which he defines as "becoming too much what we have been"; the very things that define modernity - freedom, equality, control over nature, democratic self-rule - are carried beyond feasible limits and turn against us. He mentions two versions of a possible hypertrophic form of freedom, both appropriate to modern loyalties. The first is the idea that the autonomous subject finds his purposes in himself. This perspective is a rejection of the premodern idea that human beings are set in a broader cosmic order that determines our purposes (i.e. secularisation). The hypertrophic form of modern freedom from a cosmic order undermines itself by "destroying meaning". The other fear is that the exaltation of individual freedom ends up eroding the loyalties to the community (like nationalism and patriotism) - loyalties which any society needs to survive (i.e. "a sense of impending social dissolution").

Taylor (1993:62-63) argues that we should prevent the hypertrophy of modern motives (like autonomous freedom) by developing them in an "authentic form". This view represents a strategy of reform; it implies to "rescue them in their integrity, as against the distortions and perversions that have developed in modern history". To counter the hypertrophy of individual autonomy Taylor, in communitarian mode, emphasises autonomous self-creation and self-rule through the institutions of society, which provide reasons for being loyal to these institutions. Taylor (1993:122-123, 132) regards institutions like families, churches and the state as identity-forming institutions. A person's identity assumes a "normative view of life", because it includes a vision of what is good or bad. It is important to emphasise that for the communitarian in Taylor the identity-forming institutions are "not only the point of application of a morality defined elsewhere; rather, it is the primary environment in which this morality gets elaborated". 
Taylor is nevertheless, as previously mentioned, aware of the hypertrophy of the autonomy of nations and states, which ends in a malignant nationalism or statism with no regard for modern liberal values. The hypertrophy of modern self-creative nationalism or patriotism can turn the republic from an ideal of collective freedom into an instrument of collective terror.

The question is of course whether Taylor pursues any formula to avert (reform) the hypertrophy of collective freedom. Very clear is his suggestion that forms of collective freedom can and should be the antidote against the hypertrophy of individual freedom and the meaninglessness of freedom from a cosmic order. Because of his moderate communitarian inclination, he will presumably also agree that individual freedom should be a barrier against the hypertrophy of collective freedom. Unfortunately, an important dimension is lacking: although he points out that the modern collapse of the idea of a cosmic order is one of the main causes of a loss of meaning and direction to earthly life, he does not get beyond the reinstatement of horizons of meaning created by various communities, which in its hypertrophic mode, is part of the problem. Modern reflection on this issue should (but usually do not explicitly) make room for meaning that transcends the human source, which will give a boundary and direction to both individual and collective autonomous freedom.

\section{Atomism and the politics of loyalty}

Modern autonomous freedom first appeared in an atomised cloak. This version is far from extinct and still a major alternative to jingoist nationalism and statist patriotism. The usual atomistic limitation to statism and jingoism is the idea that the state and culture is merely an instrument for individuals and should not be an object of affection. This instrumentalisation, however, breeds non-commitment, which may lead in its hypertrophic form to an undoing of collective liberty and to an impotence of the proper task of the state. In the light of problems of citizen disengagement like low voting percentages in established democracies, this non-commitment should be a major cause of concern and indeed important to explore.

Atomism's effect of non-commitment on patriotism recently surfaced in Primoratz's (2002:447-449) argument that we cannot see patriotism as a duty. He suggests that we should consider our compatriots as "a mere aggregate of individuals". One of the strong arguments for patriotism is that one owes gratitude to one's country 
because it gives life, education, language and liberty. But, rejoins Primoratz, gratitude is something that belongs to individual relations, which means gratitude to one's country is "an abbreviated way of referring to gratitude to certain specific persons who have acted within and on behalf of these large entities". Primoratz (2002:451452) justifies his opposition to patriotism (as a form of loyalty to a societal institution) with the perspective that groups are mere associations, which can be used as instruments to obtain some other goal. This view means that the unity of an association is external, justified only by cold, rational calculation.

The ontology behind this view is the atomist outlook which regards the rights of the individual as ultimate point of departure. 5 When a person enters into a communal relation with other humans, his rights are in no way affected, because the purpose of entering society is merely to protect these rights. In fact, society assumes that everybody should gain from the co-operation. This point of departure leads to the view that society is a mere instrument for the freedom and autonomy of the individual. The problem with this instrumentalisation of relations is that it "is antithetical to any strong commitment to a community"6 and on an intimate level, relationships are subservient to the "self-realisation" of the partners (Taylor, 1985b:187-188, 193; 1991a:43-44).

Instrumentalist politics manifests itself, if we use Taylor's (1991b:164-165, 177-180) jargon, in a "procedural liberalism". Proceduralism prescribes neutrality on the substance of the good life. Every individual must choose his own conception of the good. The task of the state is only to arbitrate between the demands of these conceptions with the correct "procedures of decision". The task of citizens is merely to pressurise the government to deliver on this procedural intervention. This point of view also means that participation in the governing process is not very important, as long as the government fulfils its task.

A hypertrophy of atomistic freedom thus exists; that is, the emphasis on the freedom of the individual from social pressures becomes a source of disengagement from the body politic, political impotence and ultimately a return of despotism. Taylor (1991a:112-119;

5 Cf. also Sandel (1984:85-86) and Macintyre (1995:219-220) for this communitarian analysis of atomism.

This is also Sandel's (1984:89-91) critique. 
$1989: 505,508 ; 1993: 94-97 ; 1995: 281-283)^{7}$ argues that although procedural government generates a lot of political activity, it will mainly be channelled into judicial conflicts. Connected with this activity is what he calls "interest or advocacy politics". The strategy of these politics is that of lobbying, mobilising mass opinion and selective intervention in election campaigns. These two strategies make it harder to settle important issues, because they narrow the chances of debate and compromise. The underlying tone is adversarial and prescribes that a person should get his rights, whatever the consequences for the whole.8 This stance reflects and entrenches the kind of fragmentation where citizens feel excluded from the political process and find it hard to identify with their political society. Non-identification reinforces the experience of political defencelessness against the "leviathan state". The condition for successful participation is a strong identification with the fate of the community. This is patriotism, which, according to Taylor, is "the elusive factor that is thought to make a participatory regime viable while its absence beyond a certain point makes despotism inevitable". The logic behind this view is, according to Taylor, that only such a strong loyalty to society could motivate citizens to freely take up the "burdens of a free regime", while the absence of this loyalty would require that "even the lesser burdens of a despotism be imposed by force".

Taylor identifies a hypertrophy of liberal individual freedom when individuals disengage from the political process because of an atomist ontology and instrumentalist strategy and in the end become the victims of a new despotism. He thus suggests that the alternative to this disengagement between a specific state and the universal rights of individual citizens will be to see social institutions as an essential part of the mechanism that introduces autonomous freedom (and thus also individual rights) and that loyalty to these institutions are important. This is a valid point, but probably not the whole story. One could ask whether the compromising style of

7 Sandel (1984:91-95) gives the same analysis and critique as Taylor on this point.

$8 \quad$ Kymlicka (1989:84-90) does not seem to get the point, viz. that to engage in judicial conflict merely to ensure individual rights makes compromise concerning a common goal difficult. This view is underscored when he says that "it doesn't follow that decisions are not after all made by electorates but by bureaucrats" if individuals veto majority decisions with rights politics. Lemmens (1994:121) on the other hand, agrees with Taylor that it remains questionable whether only the guarantee of rights will have any binding identification with the general interest. 
collective self-rule will in some cases not enlarge the danger of a lesser emphasis on the civil liberties (the universal values of justice and right) of individual citizens. Once again the issue of a third source for political direction (beside individual autonomy and collective self-rule), that is, a set of transcendental norms, should enter the debate.

Indeed, the secular hostility towards transcendental norms is not necessarily all that there is to modernist liberalism. Shklar (1991:29$30,34)$ makes the fear of cruelty "the basic norm" of modern political liberalism9, and this, she adds, is a "universal and especially cosmopolitan claim".10 Against the historicist and ethnocentric ideas that there are no "generally valid social prohibitions or rules", she argues that this "absolute relativism" is "too complacent and too ready to forget the horrors of our world to be credible". Shklar (1991:26-27, 29-30) nevertheless does not want too much universal content in liberalism. In what she calls the "liberalism of natural rights" of Locke, she rejects "the constant fulfilment of an ideal preestablished normative order, be it nature's or God's". It is rather hard to see how she (and for that matter, mature modernity as described by Taylor) will be able to avoid some notion of order, because she does recognise that in her "liberalism of fear" the avoidance of cruelty is "simply a first principle ... on which liberalism can be built".

\section{Structure and the politics of loyalty}

Patriotism and nationalism can be important alternatives to the sterility of an instrumentalist non-commitment. One should nevertheless take into account that these loyalties itself can go through a process of hypertrophy of the freedom it promotes and end in an exclusivism and collectivist terror. There should thus exist a relation between loyalty and goods where the two complement and not exclude one another. The hypertrophy of modernist autonomy can be traced back to the idea that freedom consists of being free from a structure for society. However, the mere notion of hypertrophy assumes in itself the possibility of a reformation of

9 This is a definition of liberalism echoed by none other than Richard Rorty (1993:xv, 74), despite his fierce opposition to any "Platonic" notions of order.

10 From the cosmopolitan corner Martha Nussbaum (2004:2) indeed alludes to something outside the human domain when she argues that jingoism actually subverts the values that hold a nation together, because it pledges allegiance to "a colorful idol" in place of "the substantive universal values of justice and right". 
freedom in which space for a connection between structure and freedom does exist.

This possibility has already been suggested in liberalism's defence of civil liberties. Freedom is, on the one hand, something that humans achieve, but it is, on the other hand, also sensed that there are some universal conditions attached to it. Taylor suggests for instance that equality and subjective rights are important for the manifestation of freedom. He (Taylor, 1993:72-73) thinks that equality and human rights are "features of modern society that have played a vital part in developing and sustaining our sense of ourselves as free agents". A dimension of the "free subject's relation to society", is according to Taylor, "that one must be the subject of rights"; as "a free subject, one is owed respect for one's rights". Nevertheless, besides these suggestions of the importance of structural principles in modernist liberty, he emphasises that freedom is also influenced by the "ability to effect one's purposes" and be able "to alter the world" - which he calls "efficacy". This ability to self-create has an individual dimension, but he emphasises that modernity has also taken up the ancient republican tradition "that only citizens are full persons capable of acting" which means the "fact that we govern ourselves is an extremely important part of our dignity as free subjects".

Taylor's emphasis of concepts like equality and rights as well as the idea of autonomy provides a more universal motivation for the politics of loyalty than that of Maclntyre (1995:210-212) who emphasises loyalty to a particular community and not the universal virtues that it should serve. This suppression of universality in patriotism assumes a disconnection between particularity and universality, which is, ironically, akin to that of Primoratz's liberal atomism. Primoratz (2002:451) prefers atomistic associations, which he admits are more fleeting and superficial but, he thinks, has as goal a more universal order of rules and values (like "fair play" and the "welfare of humanity") than that of the particularity of communal relations (like that of patriotism) where the well-being and survival of a specific and historically contingent community is foremost.

Taylor rejects the disengaging universalism of atomism and the disengaging particularism of communitarianism when, in his (Taylor, 2004a:1-2) reaction to Nussbaum's argument for a universalist cosmopolitanism, he says that to propose a cosmopolitan identity as an alternative to patriotism is a mistake, because "we have no choice but to be cosmopolitans and patriots". One of the reasons for this, he says, is that people mobilise around common identities. In 
our choice of being loyal to some identity, it is of course important that such identity be "open and hospitable to cosmopolitan solidarities". The latter seems to be universal norms, which means that to be both a cosmopolitan and a patriot is to adhere to a patriotism that is connected to, curbed and directed by universal norms.

Taylor reasons from the modern idea of freedom, which tends to disconnect freedom from any extra-human structure. Within this broad modern paradigm, he chooses to put more emphasis on the idea of a communal horizon of meaning and collective self-rule. This emphasis causes some tension in his reflections on the idea of individual freedom and the natural rights of the individual. This tension, however, does not cause him to make a strong choice for a pure communitarian politics of loyalty. Primoratz (2002:444-446, 450-451) would for instance call Taylor's patriotism a "value-based patriotism", because it comprises (partly) of a concern for one's country and compatriots, because this country embodies certain universal goods. Primoratz says that in this patriotism, it is the goods themselves and not the country that are the objects of commitment. However, he thinks that in a "true patriotism" the particular component is essential and that a "value-based" patriotism is "a mere pragmatic device for assigning to individuals some of their universal duties". For the true (non-value-based) patriot this is to miss the essential particularity of patriotism. Primoratz's analysis suggests a fundamental dualism and thus disengagement in Taylor's vision on the relation between patriotism and universal goods. 11

An atomistic liberal viewpoint, which emphasises the rights of the individual, usually leaves little space for the idea of patriotism. This emphasis on rights with the resultant exclusion of the idea of patriotism is brought about because this viewpoint sees patriotism, among other things, as a manifestation of particularism and collectivism, which undermines the universality of norms for individual existence. An extreme communitarianism, ironically, also

11 Kal (2001:182-186) also points out that Taylor's affinity for modernism means he allows for a free-floating individualist autonomy that undermines loyalty to community. Kal thinks that human beings who find themselves inside the individualist freedom ideal, will experience a limitless restlessness that will get to a rest only in a comprehensive engagement. Something like this can be experienced in the universal ideals of liberal democracy. The nature of this ideology (its emphasis on individual freedom) will cause the individual not to keep his engagements. 
subscribes to this disengagement between the universal and the particular by choosing for a patriotism that does not link with any universal goods. This tension and disengagement between goods and communal loyalty is inherent to Taylor's concept of a "valuebased" patriotism. Nevertheless, the idea of a value-based patriotism emphasises that if patriotism wants to be a necessity for the functioning of a modernist state, it can do this only in close connection with universal goods.

\section{A structural role for loyalty}

A politics of loyalty will always be viewed with suspicion as long as it is given a purely particularist character. This perception can change if the universal side of something like patriotism is also recognised; that is, if patriotism is seen as a manifestation of the moral relation between citizens and between citizens and the state.

Taylor indeed moves towards such recognition of the universality of patriotism. He (Taylor, 1991b:167-171; 1995:138-139, 141) describes the republican attitude, which he proposes as an alternative to procedural liberalism, as the ability to see political matters as a concern "for us" where this "us" are bound together by patriotism. He gives the following example to explain the difference with atomism: if my neighbour and I discuss the weather, it is a matter "for us". Before we started the discussion, it was only a matter for him and for me separately. When something becomes an "undecomposable" matter "for us", it becomes a "common good". Examples of such common goods are relations of friendships and "citizen liberty" or "participatory self-rule". 12 This description hints at patriotism as a condition for self-rule. It assumes a normative meaning when he (Taylor, 1991b:172-173) states that "citizen identification with a common good" is an important condition for a "non-despotic regime". Liberalism should have a place for a "common good, and hence patriotism, hence that it can be viable as a free society".

Taylor goes further than merely the idea that patriotism is needed for freedom and adds the equality of society as an important goal of patriotism. ${ }^{13}$ Taylor (2004a:1) remarks that "we cannot do without

12 Vandevelde (1997:126) thinks that it is possible to add the "classical law state" ("de klassieke rechtstaat") and the idea of the "welfare state" ("de klassieke welvaartsstaat") to the list of common goods.

13 Rorty $(1998: 3,15)$ agrees when he says that "national pride is to countries what self-respect is to individuals: a necessary condition for self-improvement". He 
patriotism in the modern world", because "the societies that we are striving to create - free, democratic, willing to some degree to share equally - require strong identification on the part of their citizens". He has in mind the notion that a "democracy is highly vulnerable to the alienation which arises from deep inequalities, and the sense of neglect and indifference that easily arises among abandoned minorities". This situation demands policies "with redistributive effect" and it is precisely these policies that would "require a high degree of mutual commitment". It is significant that these descriptions of the demand for patriotism is not motivated by a mere obsession to safeguard the interest of a particular community, but that patriotism becomes an important vehicle for the realisation of freedom and equality in general. One could argue that patriotism becomes in Taylor's thought a universal good in itself - a good needed for the realisation of goods like freedom and equality.

Taylor deals with the concept autonomy or self-rule in a complementary way. Self-rule becomes a universal good on which other important goods depend. He (Taylor, 1993:41; 1995:257-258, 273, 287) argues that a liberal but also republican society should be characterised by three goods, namely freedom, collective self-rule14 (republican rule) and a rule of right founded on equality. Individualistic liberalism focuses one-sidedly only on freedom, he argues. However, if collective self-rule dwindles, the individual freedom it protects will also disappear.

From the liberal corner, Primoratz (2002:452-453) accepts to some degree the communitarian argument that an individual becomes and remains a moral agent when he is informed and sustained as such by his community. The community therefore deserves patriotic allegiance. 15 But, Primoratz also says that this does not necessarily

thinks a debate and consensus on reforms is necessary if citizens want to "achieve" their country.

14 According to the original definition of Berlin (1969:121-123, 131) what Taylor calls "freedom" is actually "negative freedom" which sets limits to the control external agencies can have over some individual and, one can add, some individual community. What Taylor sees as collective self-rule is a version of "positive freedom", which suggests the empowering abilities a person or community have to effect its own destiny.

15 The same is true of Kymlicka (1992:223), a liberal, who acknowledges that liberals "still tend to take the existence of a tolerant and diverse culture for granted, as something which naturally arises and sustains itself". He therefore agrees that communitarians are correct to "insist that a culture of freedom is a 
imply "lifelong unswerving loyalty to the particular morality his community imparted in him", because the community should also provide him with the capacity to engage in moral thinking of his own. For Primoratz this is an argument not to see patriotism as a moral duty. It is as if he wants to argue that at some point the individual can and should be on his own and become the creator of his own liberty.

Taylor (1985b:206, 209, 309-310) warns, in communitarian mood, that atomists tend to assume that institutions like the rule of law, equal respect and common deliberation are simply "something given". But, argues Taylor, these goods took a long time to develop and they might disappear if not nurtured. Taylor (1985b:194-195, 197-198; 1991c:163-164) ${ }^{16}$ adds that the republican principle is not simply to support the government of the day, but rather a certain kind of society; that is an "autonomy-supporting environment". He thinks that if a person has the capacity to have moral and religious convictions, society not only has the obligation to protect her right to have certain convictions, but should also help her develop into an agent capable of "authentic conviction", because "we are dealing with a characteristically human capacity which can be aborted or distorted or underdeveloped or inhibited". Furthermore, "this commits us to an obligation to belong". If these capacities can only develop in a society of a certain kind, we ought to belong to and sustain this kind of society.

Taylor emphatically makes the point that patriotism and collective self-rule can be universal conditions for the unfolding and sustainability of goods like individual autonomy and equality. The idea of a value-based patriotism or liberal nationalism, however, underscores the notion that the relationship also goes the other way: patriotism and self-rule will not disclose themselves in a benign and normative way if they do not keep an eye on the directional influence of other universals like justice and equality. Atomists (like Primoratz) are of course correct to resist the terror of a community that enforces simply any ethos on its individual members. Terror is not

historical achievement". He therefore also argues for a "culture which supports self-determination".

16 Taylor says this in reaction to Nickel (1989:543-544), who points out that there can be "considerable dissonance between the social and legal orders" of a country. Nickel gives the example of a Chilean during the Pinochet era that may have felt a patriotic identification with Chilean society, but that this implies no duty of obedience to the laws of the Pinochet regime. 
only or even mainly due to the suffocation of the autonomy of individuals by some collectivity, but more so because of a suppression of universal moral goods, like freedom, equality and justice. This oppression can also be the work of some individual tyrant or small group of tyrants. The important diagnosis is not only about some one or some people that oppress, but also what they oppress and promote. Goods like freedom and justice are not only the product of a particular historical development, but also involve a sense that they are the manifestation of a more universal order that regulates the particular historical development. Thus, one can surely argue that if goods are not nurtured by particular communities and if they are not actively pursued by individuals, they will die. Equally, if the historical course of communities and individuals are not controlled by universal ideas, they will sink into the misery of despotism and injustice.

\section{Concluding perspective}

The main focus of this article is a search for a cosmopolitan politics of loyalty; this approach implies an attempt to reconcile the loyalty to communal spheres with a transcendental structure for society. The leading theoretical statement is that the cosmopolitan ideal demands that loyalty to family, state, nation and so on, should not transgress the functional and structural boundaries of these communal spheres, for this is the beginning of the road to totalitarianism.

In the twentieth century a fusion of patriotism and nationalism took place, which is indeed a first indication of either a totalitarian state or a totalitarian nation. A totalitarian state for instance claims control over also the cultural, ethnic and lingual identities of the nation(s) within its boundaries and thus prescribe what the cultural loyalties of its citizens should be. The reverse of this is when a national group tries to hijack the functioning of and loyalty to the state in order to safeguard and promote some ethnic, cultural or lingual identity. From a structural perspective it is therefore important to limit the loyalty to any communal sphere to the legitimate function of that sphere. It is thus necessary to distinguish between loyalty to the state (patriotism) and loyalty to the nation (i.e. ethnic, cultural or lingual group) and to insist that a legitimate patriotism implies loyalty to a state that only perform its legitimate task (i.e. to administer justice), while a legitimate nationalism implies loyalty to a nation that only aims to empower its adherents to be creators of culture.

The demands of modernist conditions lure many states into an attempt to homogenise its citizenry culturally and to ask for a fusion 
between nationalism and patriotism. Structurally this attempt implies a state overstepping its boundaries by playing the main determining role in the identity of its nations. Reaction to this situation may follow in many instances and the end result usually is an aggressive ethnic nationalism, characterised by some national grouping aspiring to hijack state power in order to undermine the homogenisation. This kind of nationalism also represents a derailment and the attempt to avoid it, implies the inspiration for the notion of a liberal nationalism. According to this kind of nationalism, the aspirations of the nation are tolerated as long as they fall within the bounds of the liberal values of freedom and equality. This boundary is made difficult by the modernist ideal of autonomy which, in its extreme form, denies any transcendental values that regulate the communal relations of people. However, any liberal outlook attempting to function without the idea of a transcendental order for society, should be questioned.

Kymlicka (1997:64) for instance thinks that a liberal nationalism arises only within a country with long-established liberal institutions. Any nationalist movement that seeks to impose illiberal elements in a population will not acquire any popular support. This claim, however, leaves some historical tendencies unexplained. After the 9/11 attack on the USA, Americans, probably inspired by some form of nationalism ${ }^{17}$, became among other things unduly obsessed with their national security ${ }^{18}$. To invade two countries (Afghanistan and Iraq) which, although not intended, caused the deaths of thousands more civilians than 9/11, are no longer within the bounds of a liberal outlook. We should remember that America claims a long tradition of liberalism. Moreover, Germany, before the Nazis, was not without liberal influence. Further back, the excesses of British imperialism were also not to be reconciled with the liberalism that was part of the British tradition.

17 Baradat (2003:59, 61) calls the USA "a very nationalistic society" and he sees this nationalism expressed in "a wave of patriotism" that "recently rushed over the United States in the wake of the terrorist attack on New York's twin towers and the Pentagon building in Washington". To this he adds that the United States has also used nationalism to justify its economic and military involvement in the Middle East.

18 This obsession with their own security is not new to Americans. In what he calls "the ideology of guaranteed security", Goudzwaard (1984:61-63) points to a similar obsession that caused the madness of the arms-race between the USA and the USSR during the Cold War. 
The point is that liberal democratic processes do not seem to be the ultimate guarantee that a derailment of public sentiment will not take place or that a population's sense of justice and morality is incorruptable. What is seen as a liberal tradition should definitely include a consciousness that a basic structure and prescription on how people should live together, is not something that can be changed by the whims of the electorate and rulers. It is important to take note that atomistic liberalism lacks a strong identification with the body politic from the side of citizens. If there is no such loyalty (patriotism), democracy (and all the rights and liberties that go with it) will not succeed. This is, however, not the only element for a democracy to be successful. In the context of a modernist outlook, important motives that push in the direction of an illiberal menace can be indicated: Extreme disconnection from a transcendental structure and the influence of this disconnection on the idea of human autonomy can erode the idea that collective self-rule should take place within general limits of moral conduct among people. A community that sees itself as the sole creator of its own liberty, gives no guarantees that it will not decide to emancipate its own members to the detriment of non-members or to force its members to be free according to some imaginary general will.

It is possible to get stuck within a tension between, on the one side, the idea that a community is the originator of its own freedom and therefore needs the strong loyalty of its citizens and, on the other side, that liberty are structured by the natural rights of its citizens. An understanding that will go a long way to soften this tension, would be a concept of loyalty as in itself a universal good that commands citizens to live in a moral way toward fellow citizens and the state itself, by adhering to goods like justice and equality. It is also clear that loyalty that goes beyond this support role for other goods and becomes an end in itself by only mobilising the power and interest of a particular communal sphere, has lost its moral import. It is therefore important to make a last suggestion: Normative concepts like loyalty, self-rule, equality, freedom and justice should be seen as conditions for one another. This means that normative concepts should be in an ongoing interaction - an interaction of mostly support, also sometimes of conflict, but never to lose contact with one another. This idea of interaction means that we can never, in a nominalistic mode, try to take leave of the idea of a transcendental structure in which all these goods should be recognised on an equal footing as valid for the way a nation organises itself. 


\section{List of references}

BARADAT, L.P. 2003. Political ideologies: their origins and impact. Upper Saddle River: Prentice Hall.

BERLIN, I. 1969. Four essays on liberty. London: Oxford University Press.

FEINBERG, W. 1997. Nationalism in a comparative mode: a response to Charles Taylor. (In McKim, R. \& McMahan, J., eds. The morality of nationalism. New York: Oxford University Press. p. 66-73.)

GOUDZWAARD, B. 1984. Idols of our time. Sioux Center: Dordt College Press.

KAL, V. 2001. Alasdair Maclntyre, Charles Taylor en de vergeten religie. (In Buijs, G.J. \& Woldring, H.E.S., reds. Grote politieke denkers: hun strijd tussen goed en kwaad. Zoetermeer: Meinema. p. 175-189.)

KYMLICKA, W. 1989. Liberalism, community, and culture. Oxford: Clarendon.

KYMLICKA, W. 1992. Contemporary political philosophy: an introduction. Oxford: Clarendon.

KYMLICKA, W. 1997. The sources of nationalism: commentary on Taylor. (In McKim, R. \& McMahan, J., eds. The morality of nationalism. New York: Oxford University Press. p. 56-65.)

LEMMENS, W. 1994. Zelf en gemeenschap: de paradox van de moderne identiteit volgens Charles Taylor. Tijdschrift voor Filosofie, 56(1):117-133.

MACINTYRE, A. 1995. Is patriotism a virtue? (In Beiner, R., ed. Theorizing citizenship. Albany: State University of New York Press. p. 209-228.)

NICKEL, J.W. 1989. Does basing rights on autonomy imply obligations of political allegiance? Dialogue: Canadian Philosophical Review, 28(4):531544.

NUSSBAUM, M. 2004. Patriotism and cosmopolitanism. http://www.phil. uga.edu/ faculty/wolf/nussbaum1.htm [17 Feb. 2004].

PRIMORATZ, I. 2002. Patriotism: a deflationary view. The Philosophical Forum, 33(4):443-458.

RORTY, R. 1993. Contingency, irony, and solidarity. Cambridge: Cambridge University Press.

RORTY, R. 1998. Achieving our country: leftist thought in twentieth-century America. Cambridge: Harvard University Press.

SANDEL, M.J. 1984. The procedural republic and the unencumbered self. Political Theory, 12(1):81-96.

SHKLAR, J. 1991. The liberalism of fear. (In Rosenblum, N., ed. Liberalism and the moral life. Cambridge: Harvard University Press. p. 21-38.)

TAYLOR, C. 1989. Sources of the self: the making of the modern identity. Cambridge: Cambridge University Press.

TAYLOR, C. 1991a. The malaise of modernity. Concord: Anansi.

TAYLOR, C. 1991b. Cross-purposes: the liberal - communitarian debate. (In Rosenblum, N., ed. Liberalism and the moral life. Cambridge: Harvard University Press. p. 159-182.)

TAYLOR, C. 1993. Reconciling the solitudes: essays on Canadian federalism and nationalism. Montreal \& Kingston: McGill-Queen's University Press.

TAYLOR, C. 1995. Philosophical arguments. Cambridge: Harvard University Press.

TAYLOR, C. 1997. Nationalism and modernity. (In McKim, R. \& McMahan, J., eds. The morality of nationalism. New York: Oxford University Press. p. 31-55.) 
TAYLOR, C. 2004a. Why democracy needs patriotism. http://www3. baylor.edu/ Scott_Moore/essays/Demo_Patriotism.html [17 Feb. 2004].

TAYLOR, C. 2004b. Modern social imaginaries. Durham: Duke University Press.

TOULMIN, S. 1992. Cosmopolis: the hidden agenda of modernity. Chicago: University of Chicago Press.

VANDEVELDE, T. 1997. Taylors kritiek van utilitarisme en liberalisme. (In Cuypers, S.E. \& Lemmens, W., reds. Charles Taylor: een mozaïek van zijn denken. Kapellen: Pelckmanns. p. 122-140.)

VIROLI, M. 1995. For love of country: An essay on patriotism and nationalism. Oxford: Clarendon.

\section{Key concepts:}

cosmopolitanism

nationalism

patriotism

Taylor, Charles

\section{Kernbegrippe:}

kosmopolitisme

nasionalisme

patriotisme

Taylor, Charles 